Repository of the Max Delbrück Center for Molecular Medicine (MDC) Berlin (Germany)

http://edoc. molc-berlin.de/13937/

\title{
Germline transgenesis in rabbits by pronuclear microinjection of sleeping beauty transposons
}

Ivics, Z., Hiripi, L., Hoffmann, O.I., Mates, L., Yau, T.Y., Bashir, S., Zidek, V., Landa, V., Geurts, A., Pravenec, M., Ruelicke, T., Boesze, Z., Izsvak, Z. 


\title{
Germline Transgenesis in Rabbits by Pronuclear
}

\section{Microinjection of Sleeping Beauty Transposons}

\author{
Zoltán Ivics ${ }^{1, *}$, László Hiripi ${ }^{2, *}$, Orsolya I. Hoffmann ${ }^{2}$, Lajos Mátés ${ }^{3}$, Tien Yin Yau ${ }^{4}$, Sanum Bashir ${ }^{5}$, \\ Vaclav Zidek ${ }^{6}$, Vladimír Landa ${ }^{6}$, Aron Geurts ${ }^{7}$, Michal Pravenec ${ }^{6}$, Thomas Rülicke ${ }^{4}$, Zsuzsanna \\ Bősze $^{2, *}$ and Zsuzsanna Izsvák ${ }^{5, *}$
}

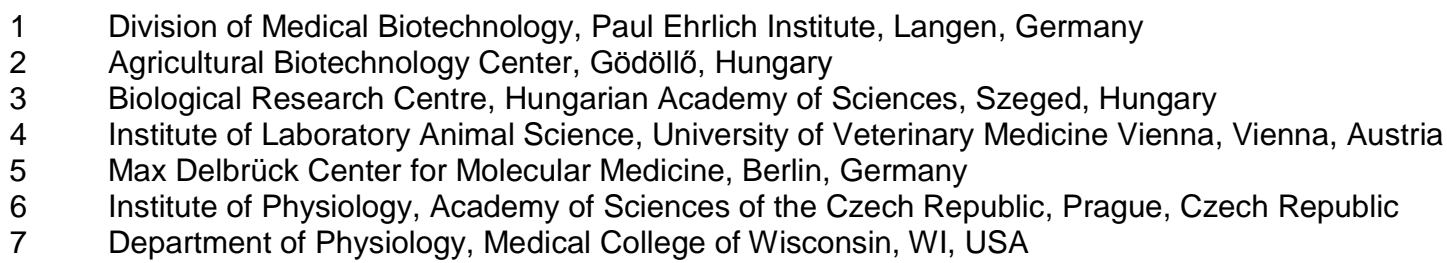

* For correspondence:
Zoltan Ivics
Paul Ehrlich Institute
Paul Ehrlich Str. 51-59
D-63225 Langen
Germany
Email: zoltan.ivics@pei.de

Zsuzsanna Izsvak

Max Delbrück Center for Molecular Medicine

Robert Rossle Strasse 10

D-13125 Berlin

Germany

Email: zizsvak@mdc-berlin.de
Zsuzsanna Bősze

Agricultural Biotechnology Center

Szent-Györgyi Albert u. 4.

H-2100 Gödöllő

Hungary

Email: bosze@abc.hu

László Hiripi

Agricultural Biotechnology Center

Szent-Györgyi Albert u. 4.

H-2100 Gödöllő

Hungary

Email: hiripi@abc.hu

\section{Key words:}

genetics, functional genomics, animal models, gene insertion, germline, transgenic, microinjection

\section{Key references:}

Katter K, Geurts AM, Hoffmann O, Mátés L, Landa V, Hiripi L, Moreno C, Lazar J, Bashir S, Zidek V, Popova E, Jerchow B, Becker K, Devaraj A, Walter I, Grzybowksi M, Corbett M, Filho AR, Hodges MR, Bader M, Ivics Z, Jacob HJ, Pravenec M, Bosze Z, Rülicke T, Izsvák Z. Transposon-mediated transgenesis, transgenic rescue, and tissue-specific gene expression in rodents and rabbits. FASEB J. 2013, 27(3):930-41.

Duranthon V, Beaujean N, Brunner M, Odening KE, Santos AN, Kacskovics I, Hiripi L, Weinstein EJ, Bosze Z. On the emerging role of rabbit as a human disease model and the instrumental role of novel transgenic tools. Transgenic Res. 2012, 21(4):699-713.

Mátés L, Chuah MK, Belay E, Jerchow B, Manoj N, Acosta-Sanchez A, Grzela DP, Schmitt A, Becker K, Matrai J, Ma L, Samara-Kuko E, Gysemans C, Pryputniewicz D, Miskey C, Fletcher B, VandenDriessche T, Ivics Z, Izsvák Z. Molecular evolution of a novel hyperactive Sleeping Beauty transposase enables robust stable gene transfer in vertebrates. Nat Genet. 2009, 41(6):753-61. 
The laboratory rabbit (Oryctolagus cuniculus) is widely used as a model for a variety of inherited and acquired human diseases. In addition, the rabbit is the smallest livestock animal that is used to transgenically produce pharmaceutical proteins in its milk. Here we describe a protocol for highefficiency germline transgenesis and sustained transgene expression in rabbits by using the Sleeping Beauty transposon system. The protocol is based on co-injection into the pronuclei of fertilized oocytes of synthetic mRNA encoding the SB100X hyperactive transposase, together with plasmid DNA carrying a transgene construct flanked by binding sites for the transposase. The translation of the transposase mRNA is followed by enzyme-mediated excision of the transgene cassette from the plasmids and its permanent genomic insertion to produce stable transgenic animals. Generation of a germline-transgenic founder animal by using this protocol takes approximately two months. Transposon-mediated transgenesis compares favorably in terms of both efficiency and reliable transgene expression to classic pronuclear microinjection, and offers comparable efficacies (numbers of transgenic founders obtained per injected embryo) to lentiviral approaches, without limitations on vector design, issues of transgene silencing as well as the toxicity and biosafety concerns of working with viral vectors. 


\section{INTRODUCTION}

The laboratory rabbit is the third most used experimental mammal (behind mice and rats) in the EU (http://eurlex.europa.eu/LexUriServ/LexUriServ.do?uri=COM:2010:0511:REV1:EN:PDF), being a prolific animal with a short generation time, that can be raised in specific pathogen-free conditions. The rabbit is the primary source of polyclonal antibodies, and recent transgenic rabbit models are capable of a significantly increased level of antibody production ${ }^{1,2}$. Transgenic rabbits are also used as bioreactors for the production of pharmaceutical proteins. Ruconest ${ }^{\circledR}$, the second milk-born recombinant product worldwide, produced and purified from transgenic rabbit's milk, has already reached the EU market (http://www.pharming.nl/index.php?act=prod).

Rodents, rabbits and other mammals all have particular limitations and strengths as animal models in biomedical research and are best regarded as complementary to each other. One example is Alzheimer disease, where animal models from additional species are expected to compensate for the limitations of mouse models and provide more reliable evaluation of novel diagnostic and therapeutic strategies ${ }^{3}$. Among the already existing transgenic rabbit strains, the models of cardiovascular diseases are the most important. The spontaneous mutant Watanabe heritable hyperlipidemic rabbit was pioneering as animal model of lipid metabolism and atherosclerosis ${ }^{4}$, and was followed by more than twenty different transgenic rabbit models, which altogether contributed to the development of both hypolipidemic and/or anti-atherosclerotic compounds ${ }^{5}$. The limitations of transgenic mouse models, which have failed to completely mimic the human phenotype of inherited long QT syndrome, an inborn arrhythmogenic heart disease, made necessary to create transgenic rabbit models ${ }^{6}$. Due to their large eyes, rabbits, along with other mid-sized and large animal models, are important in testing new treatments for and surgical methods in eye diseases ${ }^{7}$. Transgenic rabbits carrying a rhodopsin mutation showed rod-dominant progressive retinal degeneration ${ }^{8}$ and serve as pathophysiology models of new therapeutic treatments ${ }^{9}$. 


\section{Germline transgenesis in rabbits}

Since the first transgenic rabbits were created by pronuclear microinjection ${ }^{10}$, this has been the method of choice in the majority of about 200 publications on transgenic rabbits. The efficiency of this method has not changed much: on average about 1-5\% of the pups born from embryo transfer are transgenic. In addition to this low transgenesis rate, the integration site and copy number of a plasmidbased transgene is uncontrolled, therefore unwanted ectopic expression or transgene silencing might occur. Transgenesis by artificial chromosomes (YAC, BAC) ensures improved expression patterns, because those large-size vectors include most if not all the regulatory regions and the expression domains of the gene of interest $(\mathrm{GOI})^{2,11}$. However, microinjection of transgenes cloned into artificial chromosomes is technically demanding due to their large size and fragility, and the integrity of the chromosomally integrated transgene should be strictly controlled.

Lentiviral transgenesis was reported to be a promising and efficient novel tool in different nonrodent species, where the ineffective and expensive pronuclear microinjection was the only available method (for review see ref. 12). Somewhat contrary to expectations, the first data on lentiviral transgenesis in rabbit revealed that, although the SIV-based lentiviral transduction resulted in high numbers of transgenic founders, the germline transmission rate was very low due largely to mosaic transgene expression in the founder animals, making this method unsuitable for upscaling in this species $^{13}$.

Contrary to mouse, swine and ruminants, the efficiency of somatic cell nuclear transfer (SCNT) in rabbits using standard methods is very low, regardless of the type of nuclear donor cells, and only a negligible percentage of offspring remain healthy and reach sexual maturity (puberty) ${ }^{14-17}$. Therefore, this method has limited practical use in rabbit transgenesis.

\section{Transgenesis with the Sleeping Beauty transposon}

Similarly to retroviruses, DNA transposons integrate into the chromosomes of the host cells, a feature that forms the basis of their use as gene vectors. In nature, these elements contain a gene encoding a 
transposase enzyme flanked by inverted terminal repeats (ITRs) that carry binding sites for the transposase. Under laboratory conditions, transposons are applied as bi-component vector systems, in which a DNA sequence of interest can be cloned between the transposon ITRs and mobilized by supplementing the transposase enzyme in trans as an expression plasmid or as in vitro synthesized mRNA (Fig. 1A). During transposition, the transposase excises the transposon carrying the GOI from its donor plasmid, and integrates it into a chromosomal locus (Fig. 1B). Based on fossil record of transposons that were active $>10$ million years ago in fish genomes, an ancient transposon was "awakened" (molecularly reconstructed), and named Sleeping Beauty (SB) after the Grimm brothers' fairy tale ${ }^{18}$. SB was the first transposon ever shown to be capable of efficient transposition in vertebrate cells, thereby enabling new avenues for genetic engineering in animal model species (reviewed in ref. 19). In addition to SB, the piggyBac and Tol2 transposons have also been developed as gene transfer tools for vertebrate genetics ${ }^{19}$.

SB transposon-based gene delivery combines the advantages of retroviral vectors (permanent gene insertion into recipient genomes) with those of naked DNA molecules (simple, safe and inexpensive). Because transposition is a cut-and-paste mechanism that only involves DNA, transposon vectors can tolerate larger and more complex transgenes. The SB system is not strictly limited by the size of expression cassettes ${ }^{20}$. Indeed, inserts as large as BAC were recently shown to transpose with SB at reasonable efficiencies in mouse $\mathrm{ESCs}^{21}$. The desirable outcome when performing transgenesis is the integration of a single copy transgene into a genomic locus that is not disturbing endogenous gene functions. The insertional spectrum of the SB transposon satisfies this criterion well, because it integrates at TA dinucleotides nearly randomly, resulting in $\sim 60 \%$ of the SB transposon integrations being intergenic ${ }^{22-25}$. SB transposon vectors have been shown to efficiently deliver a wide variety of transgene cassettes (reviewed in refs. 19, 26 and 27), including shRNA expression cassettes to obtain stable RNAi knockdown cell lines ${ }^{28}$ as well as cassettes inducing gainof-function and loss-of-function gene mutations ${ }^{19,26,27}$. Importantly, the basic components of the transposon systems (i.e., the transposon ITRs and the transposase) are universally applicable for 
gene transfer; it is the cargo DNA cloned between the ITRs that is tailored to the intended use, i.e. mutagenesis, germline transgenesis or somatic gene therapy.

Because the transposase is only transiently present in the cell, the integrated transposon is stable (will not undergo further rounds of transposition). This feature makes transposons easily controllable DNA delivery vectors that can be used for versatile applications, including germline gene transfer. A hyperactive variant of the SB transposase, called SB100X, was recently developed by in vitro evolution $^{29}$, and shown to support efficient germline transgenesis in mice ${ }^{29-31}$, rats ${ }^{30,31}$, rabbits $^{30}$ and pigs $^{32,33}$. The SB100X-mediated protocol was optimized by carefully titrating the relative amounts of transposase and transposon to obtain optimal rates of transgenesis to generate founders, and was extensively evaluated for efficacy, toxicity, mosaicism, germline transmission, insertion site preferences, transgene copy number and silencing. Genotyping of numerous transgenic lines produced by SB-transposition demonstrated single-copy integrations of the transposon as expected from the cut-and-paste integration reaction catalyzed by the SB-transposase ${ }^{30}$. The numbers of integrations per genome was shown to be dependent on and hence controllable by the concentration of both components of the transposon system in the injection cocktail ${ }^{30}$. One of the most important aspects of using this transposon-mediated transgenic protocol is that no major mosaicism was observed, and transgene expression was maintained for several generations in all species tested. The high germline transmission rate using this protocol is in sharp contrast to any current non-viral or viral approach to transgenesis. This is likely due to the very nature of transgene integration: transposition results in precise (the ends of the integrating DNA are well defined) genomic integration of monomeric transgene units within a short timeframe following administration, thereby minimizing mosaicism. Furthermore, unlike retroviral vectors ${ }^{34-37}$, SB100X transposase-catalyzed transgene integration does not seem to trigger transcriptional silencing ${ }^{24,30}$. Therefore, the application of the Sleeping Beauty transposon system described here can significantly enhance the rabbit genomic toolbox. 


\section{Limitations}

DNA transposons, including SB, piggyBac and Tol2, are regulated by overproduction inhibition, which means that overexpression of the transposase has a negative effect on the efficiency of transposition $^{24,38}$. The practical consequence of this phenomenon is that an optimal ratio of transposon donor plasmid and transposase mRNA needs to be established. As a rule of the thumb, the injection mixture should contain $5 \mathrm{ng} / \mu \mathrm{l}$ SB100X mRNA and $0.4 \mathrm{ng} / \mu \mathrm{l}$ transposon donor plasmid for a SB vector of the total size of $\sim 6.1 \mathrm{~kb}$ (containing a $\sim 2.5 \mathrm{~kb}$ transgene cassette) ${ }^{29}$. For larger transgenes, the concentration of the donor plasmid in the microinjection mixture has to be increased to maintain optimal molar ratios between transposon and transposase. It has been found that embryos tolerate concentrations of transposon donor plasmid up to $2 \mathrm{ng} / \mu \mathrm{l}$ in $\mathrm{mice}^{29}$.

\section{Experimental Design}

The generation of transgenic rabbits by SB-mediated transgenesis is achieved through microinjection of a plasmid carrying a GOI cloned between the ITRS of SB, and synthetic transposase mRNA (Fig. 1) into the pronucleus of a zygote, with frequencies of transgenic founders (per born live pup) of $15 \%$ or higher $^{30}$. The protocol consists of the following major stages:

Preparation of Sleeping Beauty transposon components for microinjection (Steps 1-26). This includes molecular cloning of a GOI into SB transposon vectors; preparation of mRNA encoding the transposase by in vitro transcription; and preparation of a nucleic acid mixture consisting of the purified transposon plasmid and the transposase mRNA. Synthetic mRNA encoding the SB100X transposase can be produced from either the pCMV(CAT)T7-SB100X or the pcGlobin2-SB100X plasmids $^{29}$ (see Reagents). The latter vector supports in vitro synthesis of SB100X mRNA containing zebrafish $\beta$-globin 5'- and 3'-UTRs and a 30-mer synthetic poly(A) sequence, from a T7 promoter ${ }^{39}$. Transgenesis with Sleeping Beauty in rabbits (Steps 27-49). This includes preparation of donor animals, superovulation of donors, collection of zygotes, microinjection of the nucleic acid mixture into zygotes and transfer of the microinjected embryos into surrogate mothers. The exact timing of superovulation and embryo collection is critical, and needs to be optimized to obtain sufficient numbers of 
freshly fertilized, one cell-stage oocytes with clearly visible pronuclei. Contrary to mouse, rat and swine, the early development of rabbit embryos is rapid, therefore it could easily happen that some of the embryos will be in the two-cell stage by the time the embryo collection is finished. For the same reason it is not suggested to significantly increase the number of donor does per experimental day.

Genotyping of transgenic animals (Steps 50-76). This includes PCR-based analysis of F0 as well as F1 offspring to establish founders and germline transmission. A simple, quick PCR test can be applied to determine the presence of integrated transposon sequences from genomic DNA samples. The PCR primers amplify sequences in the left ITR of SB; thus, this protocol can be universally applied irrespective of the GOI that was cloned into the SB vector. In order to assess copy numbers of integrated transposons and map the genomic integration sites, a ligation-mediated PCR procedure is applied $^{40}$. The procedure consists of a restriction enzyme digest of the genomic DNA, ligation of an oligonucleotide adapter to the ends of the fragmented DNA, PCR amplification of a transgene/genomic DNA junction in two rounds of nested PCR with primers specific to the adapter and to the ITRs of the SB transposon, and sequencing of the junctions to map the insertion to the reference genome ${ }^{41}$. Finally, a locus-specific PCR is applied to distinguish and track the individual integrations in the F1 and later generations.

\section{MATERIALS}

\section{Reagents}

\section{Animals}

10 donor and 10 recipient rabbits are sufficient to produce at least two independent transgenic founders in a well-managed animal unit with trained personnel. The most frequently used breed for transgenesis is the New Zealand White (Harlan Laboratories, Indianapolis), but depending on the aim of the experiment, it could be replaced with Hycole (Sarl Hycole, Marcoing, France) or ZIKA ${ }^{\circledR}$ hybrid rabbits (Dr. Zimmermann GbR, Schweizerhof, Germany). In some countries local breeds are also successfully used e.g. Japanese White rabbits in Japan and China (KBT Oriental Corporation, Saga, Japan). Laboratory rabbits can also be 
obtained from the distributors of Charles River (Charles River Laboratories International Inc., USA) or from authorized local breeders. The rabbit does should be sexually mature and at an age of 16-20 weeks, weighing $3.0-3.5 \mathrm{~kg}$ on average. The rabbit bucks should be at least 18-20 weeks old to provide good quality semen.

! Caution Experiments involving rabbits must conform to national and institutional regulations. Animal handling requires special license(s).

\section{Molecular biology reagents}

- mMessage mMachine ${ }^{\circledR}$ T7 kit (Invitrogen/Ambion, cat no. AM1344)

- Plasmid DNA preparation kit (Qiagen, cat no. 27106)

- QIAquick Gel Extraction Kit (Qiagen, cat no. 28704)

- Agarose (DNase, RNase none detected) (Sigma-Aldrich, cat no. A4718)

- Ethidium bromide (Sigma-Aldrich, cat no. E1015-10ml)! Caution This is a hazardous chemical. Avoid contact with skin, eyes and airways.

- Clal restriction endonuclease (New England Biolabs, cat no. R0179S)

- Bfal restriction endonuclease (New England Biolabs, cat no. R0568S)

- Dpnll restriction endonuclease (New England Biolabs, cat no. R0543S)

- Taq DNA polymerase, provided with PCR buffer (10X) and $\mathrm{MgCl}_{2}(25 \mathrm{mM})$ (New England Biolabs, cat no. M0267S)

- Oligonucleotides (Integrated DNA Technologies, Inc.)

- $\quad$ dNTP (10 mM) (New England Biolabs, cat no. N0447S)

- Sodium chloride (Sigma-Aldrich, cat no. S3014)

- Sodium acetate 3 M pH 5.5 (RNase-free) (Invitrogen/Ambion, cat no. AM9740)

- RNaseZap (Invitrogen/Ambion, cat no. AM9780)

- 2-propanol (ROTH, cat no. 6752.1)

- Ethanol (RNase-free) (MERCK, cat no. 108543) 
- Water (RNase-free, filtered) (Sigma-Aldrich, cat no. W4502) CRITICAL The use of filtered RNasefree water is recommended in solutions coming in contact with the injection material.

- Phenol/chloroform/isoamyl alcohol, Roti®-Phenol/C/I (ROTH, cat no. A156.2) ! Caution This is a hazardous chemical. Avoid contact with skin, eyes and airways.

- Chloroform/isoamyl alcohol, Roti®-C/I (ROTH, cat no. X984.2)! Caution This is a hazardous chemical. Avoid contact with skin, eyes and airways.

- DEPC (Sigma-Aldrich, cat no. D5758)! Caution This is a hazardous chemical. Avoid contact with skin, eyes and airways.

- 5x TBE buffer, Nuclease-free (Sigma-Aldrich, cat no. 93306)

- TE buffer (Sigma-Aldrich, cat no. 93283)

- T4 DNA ligase, provided with ligase buffer (10X) (New England Biolabs, cat no. M0202S)

- 100-bp DNA Ladder (Thermo Scientific, cat no. SM0242)

- 100-10.000-bp DNA Ladder (Thermo Scientific, cat no. SM0331)

- pGEM-T Vector Systems (Promega, cat no. A3600)

- Transposon donor plasmid: pT2/BH (http://www.addgene.org/26556/) or pT2/HB (http://www.addgene.org/26557/) are available from Addgene.

- Transposase expression plasmids: pCMV(CAT)T7-SB100X (http://www.addgene.org/34879/) is available from Addgene, and pcGlobin2-SB100X is available from Dr. Zsuzsanna Izsvak, Max Delbrück Centrum for Molecular Medicine, Berlin.

\section{Animal work}

- Injection buffer, EmbryoMax® (Millipore, cat no. MR-095-10 F)

- PBS, pH 7.4: (Sigma-Aldrich, cat no. P4417)

- Millipore Express PLUS membrane $0.22 \mu \mathrm{m}$ (Merck Millipore, cat no. GPWP01300)

- Repel-Silane (Sigma-Aldrich, cat no. Z719951-1CS)

- Heat-inactivated FCS (Gibco, cat no. 10500-064)

- Mineral oil/Embryo tested (Sigma-Aldrich, cat no. M8410) 
- Penicillin/streptomycin (100x) (Gibco, cat no. 15140-122)

- Medasept coloured skin desinfectant (Molar chemicals, cat no. 41730-000-310)

- $10 \%$ ketamine (CP-Ketamin, Cp-Pharma Handelsges mbH)

- 2 \% xylazine (CP-Xilazin, Cp-Pharma Handelsges mbH)

- Pregnant mare's serum gonadotropin (PMSG) (Sigma-Aldrich, cat no. G4877)

- Human chorionic gonadotropin (hCG) (Sigma-Aldrich, cat no. C1063)

- Gonadotropin releasing hormone (GnRH) (Sigma-Aldrich, cat no. L8008)

- Follicle stimulating hormone (pFSH) (Sigma-Aldrich, cat no. F2293)

- Oxytocin (Sigma-Aldrich, cat no. O3251)

- Betadine solution (Fisher Scientific, cat no. NC9238358)

- Shotapen INJ broad-spectrum antibiotics (Virbac Animal Health)

\section{EQUIPMENT}

\section{For molecular biology}

- Refrigerated centrifuge capable of high speed $(12000 \times g)($ Thermo Scientific, cat no. 75008162$)$

- Water bath, $37^{\circ} \mathrm{C}$ (Thermo Scientific, cat no. 2824)

- NanoDrop® ND-2000 Spectrophotometer (Thermo Scientific, cat no. 91-ND-2000)

- Milli-Q Water Purification System (Merck Millipore, cat no. ZRXQ003T0)

- 1.5-ml tubes, free of DNase and RNase (Eppendorf, cat no. 0030123.328)

- Pipette tips, free of DNase and RNase (Eppendorf, cat no. 0030077.504 (0.1- $10 \mu l)$, cat no. $0030077.539(2-20 \mu \mathrm{l})$, cat no. $0030077.555(2-200 \mu \mathrm{l})$, cat no. $0030077.571(50-1000 \mu \mathrm{l}))$

- Thermal cycler capable of temperature increments for touchdown PCR (Thermo Scientific, cat no. TCA0001)

- Electrophoresis apparatus including running chamber, well combs, gel tray and power supply (BioRad, cat no. 164-5050)

- $100-m l$ glass flasks (SIMAX, cat no. B1812) 


\section{For animal work}

- Microcapillaries (Harvard Apparatus, GC100-T15 cat no. 30-0036 and GC100-TF15 cat no. 30-0039, Brand cat no. 701902) ! Caution These are sharp objects; dispose in an institution-approved container.

- Engraving pen (Sigma-Aldrich, cat no. Z225568-1EA)

- Bunsen burner (Sigma-Aldrich, cat no. Z270318-1EA)

- Mouthpiece, 15-inch aspirator tube and microcapillary holder (Sigma-Aldrich, cat no. P0799)

- Transfer capillary setup (home-made, $1 \mathrm{ml}$ syringe with/brand capillary) ! Caution These are sharp objects; dispose in an institution-approved container.

- Suture wound clips (Metal suture clips for mice, $7 \mathrm{~mm}$ ) (Leica, cat no. 39465204)

- Introcan Safety IV indwelling cannula (BBraun, cat no. 4254171B) ! Caution These are sharp objects; dispose in an institution-approved container.

- 18-gauge mixing needle (Terumo Medical Corporation, cat no. BN-1838)

- 20-ml syringe (Terumo Medical Corporation, cat no. SS+20L1)

- 35-mm cell culture dishes (WWR, cat no. 734-2342P)

- 100-mm cell culture dishes (WWR, cat no. 734-2341P)

- Dissection tools: two forceps (WWR, cat no. RSGA011.130), sterile scalpel (VWR, cat no. 233-0112), surgical scissors (VWR, cat no. 233-1104) ! Caution These are sharp objects.

- Warming plate (Minitüb, cat no. 12055/0200)

- Electrical hair cutter/clipper (Oster, cat no. 76076-010)

- Depressed microscope slide (Omnilab, cat no. 5161151)

- Veress Pneumoperitoneum Needle (Storz, cat no. 26120JLL)! Caution This is a sharp object.

- 2.7-mm Hopkins telescope with 30-degree oblique view (Storz, cat no. 64018BSA)

- Cold light fountain halogen, at least 150 W (Storz, cat no. 20131520)

- Rubber insufflation bulb (Storz, cat no. 40924B)

- Sharp obturator for arthroscope sheaths (Storz, cat no. 28126BS) ! Caution This is a sharp object.

- $\quad$ Arthro sheet (Storz, cat no. 28126) 
- Stereoscopic microscope with top and bottom illumination (Olympus, cat no. SZX7)

- Inverted microinjection microscope with DIC optic (Olympus, cat no. IX-71)

- $2 \times$ Micromanipulator (Narishige, cat no. MMO-202ND)

- Microinjector (Eppendorf, cat no. 5247000.013)

- $\mathrm{CO}_{2}$ incubator (Nuaire, cat no. Nu 4950E)

- Microforge (Narishige, cat no. MF-900)

- Capillary puller (Sutter Instrument, cat no. P-97)

- Injection holder set (Narishige, cat no. IM-H1)

\section{REAGENT SETUP}

DEPC treatment of water. Add $1 \mathrm{ml}$ DEPC to $1 \mathrm{~L} \mathrm{Milli-Q}$ water to make a $0.1 \%$ (vol/vol) solution and shake vigorously. Continuously stir the solution for 12 hours at room temperature $\left(\sim 20^{\circ} \mathrm{C}\right)$. Autoclave it for $1 \mathrm{~h}$ to remove any trace amount of DEPC, as residual DEPC reacts with purine residues in RNA.

$\mathrm{NaCl}$ solution for oligonucleotide annealing. Prepare a $500 \mathrm{mM} \mathrm{NaCl}$ stock solution in Milli-Q water, and sterilize with autoclaving or filtration. Prepare the working solution by diluting the stock 10x in sterile TE buffer. Keep frozen at $-20^{\circ} \mathrm{C}$.

Quality control of synthetic mRNA on agarose gel. Clean the running chamber, gel tray, comb and flask for gel preparation with $70 \%$ (vol/vol) ethanol and decontaminate them from RNases with RNaseZap. Rinse the reagent off with RNase-free Milli-Q water (DEPC-treated). Incubate $1 \mu \mathrm{l}$ of in vitro synthesized mRNA in $10 \mu \mathrm{l}$ injection buffer for 1 hour at $37^{\circ} \mathrm{C}$ and run on an RNase-free $1 \%$ (wt/vol) agarose gel.

PBS $+20 \%$ (vol/vol) FCS medium. Add $20 \mathrm{ml}$ of FCS to $80 \mathrm{ml} \mathrm{PBS}$, and sterilize the solution with a $0.22 \mu \mathrm{m}$ membrane filter. 
TBE. DEPC cannot be used directly to treat Tris buffers. To prepare TBE, dilute the nuclease-free $5 \mathrm{X}$ TBE (see Reagents) in DEPC-treated water.

\section{EQUIPMENT SETUP}

Microinjection slides. The depressed microscope slides should be immersed briefly in Repel-Silane, air-dried for a few minutes, rinsed with water and autoclaved before each experiment.

Preparation of capillaries. Injection capillary: Prepare an injection capillary with a tiphole 1-2 $\mu \mathrm{m}$ according to the manual of the puller. It is not possible to provide exact pulling data because each type of heating filament requires different conditions. Further instructions can be found at www.shutter.com/contact/faqs/pipette_cookbook.pdf. Holder capillary: Pull your holding capillary manually under a bunsen burner with a $100 \mu$ m outside diameter. Prepare a $30 \mu \mathrm{m}$ hole of your holding capillary using a microforge. Alternatively, all capillaries can be purchased from distributors (e.g. Eppendorf).

\section{PROCEDURE}

CRITICAL At each step of the protocol use RNase-free plasticware and reagents and wear gloves while handling reagents and samples to prevent RNase contamination.

\section{Preparation of RNase-free transposon (transgene) donor plasmid $\square \operatorname{TIMING} 2-4 \mathrm{~h}$}

1 Clone your GOI between the ITRs of a SB transposon donor plasmid (e. g., pT2/HB; see Reagents) by standard molecular cloning procedures.

2 Transfer at least $5 \mu \mathrm{g}$ transposon donor plasmid in $400 \mu \mathrm{l} \mathrm{TE}$ buffer into a $1.5 \mathrm{ml}$ tube, and add $400 \mu \mathrm{l}$ phenol/chloroform/isoamyl alcohol to the tube. ! Caution This is a hazardous chemical. Avoid contact with skin, eyes and airways.

3 Vortex the tube for $15 \mathrm{~s}$ and leave it on the bench for $2 \mathrm{~min}$. Repeat this step 3 times to completely inactivate residual RNase.

4 Centrifuge at $12000 \times g$ for $5 \mathrm{~min}$ at room temperature. 
5 Transfer the top layer to a new, RNase-free $1.5 \mathrm{ml}$ tube and add $400 \mu$ l chloroform/isoamyl alcohol. ! Caution This is a hazardous chemical. Avoid contact with skin, eyes and airways.

6 Vortex for $15 \mathrm{~s}$ and centrifuge at $12000 \times \mathrm{g}$ for $5 \mathrm{~min}$ at room temperature.

7 Transfer the aqueous top layer, containing the DNA, to a new RNase-free $1.5 \mathrm{ml}$ tube, add 1/10 volume of $3 \mathrm{M}$ sodium acetate and 2.5 volumes of ethanol, vortex briefly, and precipitate the DNA for 30 min at $-20^{\circ} \mathrm{C}$.

8 Spin down at $12000 \times g$ for $15 \mathrm{~min}$ at $4{ }^{\circ} \mathrm{C}$ and discard the supernatant.

9 Wash the pellet in cold $70 \%$ (vol/vol) ethanol (RNase-free) by keeping the ethanol on the pellet for 10 min on ice, centrifuge at $12000 \times g$ for $1 \mathrm{~min}$ at $4{ }^{\circ} \mathrm{C}$, and discard the supernatant. Repeat this step to completely remove any residual chemicals that may not be tolerated by the embryos. CRITICAL STEP DEPC is not tolerated by the embryos and RNase-free solutions that come in contact with the injected material should be purified by filtration. Therefore, use filtered, RNase-free water for the preparation of $70 \%$ ethanol.

10 Air-dry the pellet for 5-10 min and resuspend it in $100 \mu$ l EmbryoMax® injection buffer.

11 Measure the concentration of the plasmid DNA using a NanoDrop ${ }^{\circledR}$ spectrophotometer.

12 Make a $50 \mathrm{ng} / \mu \mathrm{l}$ dilution of the plasmid in EmbryoMax® injection buffer. This dilution can be used later for the preparation of the final injection mixture (Steps 25-26).

Pause Point The plasmid stock and its dilution can be stored (preferably at $-80^{\circ} \mathrm{C}$ ) until use for up to 2 years.

13 Thaw the plasmid DNA immediately before the preparation of the microinjection mixture (Step 25).

\section{Preparation of the transposase mRNA $\square T I M I N G$ 10-14h}

14 Linearize at least $2 \mu \mathrm{g}$ of the pcGlobin2-SB100X plasmid with Clal digestion; $1 \mu \mathrm{g}$ of linearized plasmid will be necessary for one round of mRNA synthesis. Check complete linearization on a 1 $\%$ (wt/vol) agarose gel. 
CRITICAL STEP Supercoiled plasmid DNA runs faster, whereas open circular plasmid runs slower on agarose gel than the linear form. Following full digestion, bands corresponding to the open circular and supercoiled forms of the plasmid should be no longer visible on the gel. Consequently, linearized plasmid DNA produces a single band corresponding to the size of the plasmid when compared to a linear DNA ladder size marker.

15 Prepare the digested plasmid RNase-free by phenol/chloroform extraction as described in steps 2-10. In steps 2 and 5, set the volumes of the digested plasmid DNA, the phenol/chloroform/isoamyl alcohol and the chloroform/isoamyl alcohol to $100 \mu$ l each. This will decrease the liquid volume during precipitation and improve DNA recovery.

16 Measure the concentration of the linearized plasmid DNA using a NanoDrop ${ }^{\circledR}$ spectrophotometer.

17 Synthesize the mRNA using the mMessage mMachine ${ }^{\circledR}$ T7 kit following the manufacturer's instructions.

18 After mRNA synthesis, perform the Turbo DNase treatment and phenol/chloroform extraction suggested in the mMessage mMachine ${ }^{\circledR}$ T7 kit manual, with the modification that after the isopropanol precipitation following the phenol/chloroform extraction, wash the pellet twice in cold $70 \%$ (vol/vol) ethanol. Use filtered, RNase-free water for the preparation of $70 \%$ ethanol. Airdry the pellet for 5-10 $\mathrm{min}$.

19 Resuspend the mRNA in $20 \mu$ filtered, RNase-free water.

Pause Point The in vitro synthesized mRNA can be stored at $-80{ }^{\circ} \mathrm{C}$ for 6 months.

20 Measure the concentration of the in vitro synthesized mRNA using a NanoDrop ${ }^{\circledR}$ spectrophotometer. The typical yield is around $1 \mu \mathrm{g} / \mu \mathrm{l}$.

21 Prepare a $1 \%$ (wt/vol) agarose gel using nuclease-free TBE buffer, Milli-Q water treated with DEPC and agarose powder. ! Caution DEPC is a hazardous chemical. Avoid contact with skin, eyes and airways. 
22 Load $1 \mu$ of the in vitro synthesized mRNA (Step 19) in RNA loading buffer (supplied in the mMessage mMachine ${ }^{\circledR}$ T7 kit) and a double-stranded DNA size marker and run the gel. The SB100X mRNA prepared using the T7 promoter on the Clal-digested pcGlobin2-SB100X runs on a normal agarose gel as one band between 700-800 bp in length (Fig. 2).

\section{? TROUBLESHOOTING}

23 Prepare $10 \mathrm{ng} / \mathrm{\mu l}$ dilution of the mRNA (Step 19) in EmbryoMax® injection buffer, and freeze down $5 \mu$ l aliquots of this dilution.

Pause Point The $10 \mathrm{ng} / \mu \mathrm{l}$ mRA dilutions can be stored at $-80^{\circ} \mathrm{C}$ for 6 months.

CRITICAL STEP It is advisable to test new batches of the EmbryoMax® injection buffer for accidental presence of RNase (see Reagent Setup) as the manufacturer does not guarantee that it is RNasefree.

\section{Preparation of the microinjection mixture $\square$ TIMING $1 \mathrm{~h}$}

24 Thaw one aliquot of the $10 \mathrm{ng} / \mu \mathrm{l}$ mRNA solution immediately before the preparation of the microinjection mixture (Step 25).

CRITICAL STEP Avoid repeat thawing and freezing of mRNA stocks as it may cause mRNA degradation.

25 Prepare $5 \mu$ l donor (transgene) plasmid (from the stock solution prepared in Step 12) in a concentration of $0.8 \mathrm{ng} / \mu \mathrm{l}$ in EmbryoMax ${ }^{\circledR}$ injection buffer.

26 Mix the mRNA and donor plasmid solutions at a 1:1 ratio to create the final microinjection mixture. Prepare $2 \mu \mathrm{l}$ aliquots of the final microinjection mixture.

Pause Point Frozen aliquots of the microinjection mixture may be stored at $-80{ }^{\circ} \mathrm{C}$ for a couple of months.

\section{Superovulation and insemination of zygote donors $\square$ TIMING 5 days}

27 To produce zygotes for pronuclear injection of the Sleeping Beauty transposon vectors, superovulate 
3-8 rabbit does (3-3.5 $\mathrm{kg}$ body weight), either by following two different superovulation procedures described as Options A or B (Fig. 3), and mate or artificially inseminate them with buck semen from the same breed.

A. Superovulation of donor does with $\mathrm{pFSH/hCG:}$

i. Inject follicle stimulating hormone pFSH (13.5 mg FSH/donor) subcutaneously six times, 12 hrs apart.

ii. Induce ovulation with an intravenous injection of 75 IU human chorionic gonadotropin (hCG) at 85 hours after the first pFSH injection. Fertilize the donor does by mating or by artificially inseminating them with fresh semen, at the time of the hCG injection.

iii. Collect embryos 20 hours after fertilization.

B. Superovulation of donor does with PMSG/hCG:

i. Prime the animals with intramuscular injection of $120 \mathrm{IU}$ pregnant mare serum gonadotropin (PMSG) per animal, 116 hours before intended embryo collection.

ii. Inject the animals intravenously with $180 \mathrm{IU}$ hCG per animal and fertilize them at 72 hours after the PMSG injection.

CRITICAL STEP The timing of superovulation is critical (see Experimental Design); therefore, in case of using superovulation option B, it is practical to introduce both PMSG as well as hCG at 13:00 in the appropriate days, allowing embryo collection $20 \mathrm{~h}$ after the $\mathrm{hCG}$ injection and mating; $i$. e., in the morning on the following day.

\section{Zygote collection $\square$ TIIMING 1-2 h}

CRITICAL Trained personnel with the appropriate permission are required for performing Steps 28-33.

28 Euthanize the donor females with a mixture of $0.8 \mathrm{ml} 2 \%$ xylazin and $1.4 \mathrm{ml} 10 \%$ ketamin intravenously at 9:00 am (Fig. 3).

29 Rinse the abdomen of donor animals with $70 \%$ (vol/vol) ethanol and firmly remove the skin from their abdomen.

30 Incise the peritoneum. 
31 Collect the reproductive organs (ovaries, oviducts and the cranial parts of the uterus horns; Fig. 4A) and place them into PBS in a dish on a warm plate at $38.5^{\circ} \mathrm{C}$.

CRITICAL STEP The reproductive organs are surrounded by fat tissue. Care has to be taken to avoid scraping or damaging the oviduct.

32 Place your capillary (GC100-T15) into the microcapillary holder. Place 2-3 drops of PBS $+20 \%$ FCS medium into a 35-mm cell culture dish, overlay the droplets with mineral oil and place the dish into a $\mathrm{CO}_{2}$ incubator at $38.5^{\circ} \mathrm{C}$.

33 Collect zygotes 20 hours after hCG treatment and mating (Step 27). Insert an 18-gauge mixing needle connected to a $20-\mathrm{ml}$ syringe from the uterus side (if this is not possible, try to wash from the ovary side). Flush each oviduct with pre-warmed (to $38.5^{\circ} \mathrm{C}$ ) PBS $+20 \%$ FCS into $35-\mathrm{mm}$ cell culture dishes. By counting the ovulatory follicles on the ovaries, the number of expected oocytes can be estimated (Fig. 4B).

CRITICAL STEP The oviduct should be thoroughly rinsed by culture medium.

\section{? TROUBLESHOOTING}

34 Place 3-4 drops of PBS + 20 \% FCS medium into a 100-mm cell culture dish, and separate healthy zygotes from debris (Fig. 4C) by washing them through the medium drops. Good quality embryos are free of cumulus cells and have two easily detectable pronuclei. Place the washed zygotes into the medium droplets overlayed with mineral oil (Step 32), and place the dish into a $\mathrm{CO}_{2}$ incubator at $5 \% \mathrm{CO}_{2}, 38.5^{\circ} \mathrm{C}$ until microinjection, for an hour.

CRITICAL STEP Debris should be completely removed from the medium for optimal microinjection. ? TROUBLESHOOTING

\section{Microinjection of zygotes $\square$ TIIMING 1-3 h}

35 Thaw the purified mRNA/plasmid DNA final microinjection mixture (Step 26) immediately before injection and keep on ice till loading your injection capillary.

CRITICAL STEP Avoid repeated thawing and refreezing of the microinjection solution.

36 Place a $15-20 \mu \mathrm{l}$ drop of PBS $+20 \%$ FCS medium in the center of a cleaned and autoclaved 
depressed microscope slide. Cover the droplet with mineral oil.

37 Place 20-40 zygotes into the drop and place under a stereoscopic microscope (Fig. 4D).

CRITICAL STEP Do not handle too many zygotes at once.

38 Place the depressed slide onto the heated stage of the microinjection microscope.

39 Adjust the air-driven holding capillary to an angle of $35-40^{\circ}$, and carefully dip into the medium droplet in the depressed microscope slide. Fill the capillary with a minimal amount of medium and catch the first embryo by a slight negative pressure.

40 Fill the injection capillary (GC100-TF15) by placing the base of the capillary into the Eppendorf tube containing the microinjection mixture kept on ice. Wait 10 seconds till the mixture reaches the tip of the capillary. Insert the injection capillary into the connector piece and dip it into the medium droplet. Position it to the zygote.

CRITICAL STEP Prevent breakage of your capillaries. Remove all air bubbles from the injection capillary. 41 Position your zygote - the best position is when the female and the male pronuclei are aligned in a row equatorially. Focus your microscope to the male pronucleus (usually the larger one) and adjust your injection capillary to see the tip of it sharply when it is in a 12 o'clock position. Keep your injection capillary parallel to the pronucleus (Fig. 4E). Penetrate the zygote and the pronucleus, and inject carefully by pushing your syringe or automatic microinjector. Withdraw the capillary when the male pronucleus is swelling (Fig. 4F). Microinject all viable zygotes one by one.

CRITICAL STEP Be sure that you penetrate the pronucleus because it is very flexible. The clearly visible swelling of the pronucleus is an indication of injecting $\sim 2-3 \mathrm{pl} \mathrm{mRNA/plasmid} \mathrm{solution.} \mathrm{The} \mathrm{female}$ pronucleus can also be injected. In some cases the female pronucleus is more visible in rabbits (rabbit zygotes can be darker than rodents'); however, it is smaller and more difficult to inject.

CRITICAL STEP If your injection capillary becomes clogged, replace it with a new one. CRITICAL STEP Carefully separate injected and uninjected zygotes to prevent mixing. 


\section{Reimplantation of injected zygotes $\square T I M \| N G$ 15-30 min/recipient}

CRITICAL Trained personnel with the appropriate permission are required for performing these steps.

42 To prepare recipient does, apply a single intramuscular injection of $0.25 \mathrm{ml} \mathrm{GnRH} 24$ hours before embryo transfer (Fig. 3). Remove forage from recipient does 12-14 hours before embryo transfer.

43 Culture the microinjected embryos for one hour in $5 \% \mathrm{CO}_{2}$ at $38.5^{\circ} \mathrm{C}$ before reimplantation and select the embryos most suitable for embryo transfer (Fig. 4G).

\section{? TROUBLESHOOTING}

44 Anesthesize recipient females with a mixture of $5 \mathrm{mg} / \mathrm{kg}$ body weight $2 \%$ xylazin and $44 \mathrm{mg} / \mathrm{kg}$ body weight $10 \%$ ketamin intravenously. Anesthesia lasts 30-45 min.

CRITICAL STEP Introduce the ketamine and xylazin solution stepwise and slowly. Fast administration might cause bradycardia.

45 Remove the rest of the urine with gentle massage of the lower part of the donor's body. Shave the abdominal region of the anesthetized recipient doe, and clean with a surgical soap solution such as betadine. Place and fix the recipient doe in a hanging position. Introduce the endoscopic trocar (Veress Pneumoperitoneum Needle) through a small $(1 \mathrm{~cm})$ incision just above the umbilical point as shown in Fig. $\mathbf{4 H}$.

46 Inflate the abdomen with air using the rubber insufflation bulb. Remove the Veress trocar and insert the arthro sheet with sharp obtulator. Replace the obtulator with Hopkins telescope. Reinflate the abdomen.

\section{CRITICAL STEP Avoid injury of inner organs.}

47 Examine the ovaries of the recipients for signs of induced ovulation (such as those shown in Fig. 4A). Do not transfer embryos into recipients that did not react to hormone treatment.

48 Insert the cannula with its needle, and find the ampulla of the oviduct. Exchange the needle with the transfer capillary filled with the embryos through the cannula, and inject it gently with $10 \mu$ of culture medium (Fig. 4I). Remove the cannula with the empty capillary and the endoscope. Evacuate the air and close the abdomen with a suture wound clip. Transfer 8-12 embryos into each oviduct of a recipient doe. Endoscopic embryo transfer is minimally invasive ${ }^{42}$. 
49 Post-operative care: administer $1 \mathrm{ml}$ broad-spectrum antibiotics (Shotapen INJ) intraperitoneally. Place the recipient rabbit carefully into the home cage in the rabbit facility and resupply forage when animals fully have recovered from the anesthesia. F0 animals are born after a 30-32 days-long pregnancy of recipient does.

CRITICAL STEP A specific feature of the rabbit embryo is a mucin layer, which is formed around the embryo in the oviduct. The thickness of the mucin layer is an important factor for successful implantation of rabbit embryos ${ }^{43}$. Therefore, it is important to transfer the embryos as soon as possible following a short in vitro culturing, at the end of which $20-80 \%$ of the injected rabbit embryos should be in two-cell stage before reimplantation. Keep in mind that due to the rapid cell divisions during early embryogenesis, mosaicism is more probable in rabbits than in rodents.

\section{? TROUBLESHOOTING}

\section{Genotyping of transgenic animals - confirming transposon insertions by PCR $\square$ TIIMING 2.5 hours}

50 Isolate genomic DNA from ear biopsies of F0 animals. A simple and reliable protocol for DNA isolation from tissue samples is available in Laird et al. $(1991)^{44}$.

51 Set up a PCR reaction in a $25 \mu$ l volume containing the components below:

\begin{tabular}{lll}
\hline Component & Amount per reaction & Final \\
\hline PCR buffer $(10 \mathrm{x})$ & $2.5 \mu \mathrm{l}$ & $1 \mathrm{x}$ \\
$\mathrm{MgCl}_{2}(25 \mathrm{mM})$ & $1.5 \mu \mathrm{l}$ & $1.5 \mathrm{mM}$ \\
dNTP $(10 \mathrm{mM})$ & $0.5 \mu \mathrm{l}$ & $0.2 \mathrm{mM}$ \\
Primer SB short $(10 \mathrm{pmol} / \mu \mathrm{l})($ Table 1$)$ & $0.8 \mu \mathrm{l}$ & $8 \mathrm{pmol}$ \\
Primer Tbal rev $(10 \mathrm{pmol} / \mu \mathrm{l})($ Table 1$)$ & $0.8 \mu \mathrm{l}$ & $8 \mathrm{pmol}$ \\
Genomic DNA & $1 \mu \mathrm{l}$ & $\sim 200 \mathrm{ng}$ \\
Taq DNA polymerase & $0.4 \mu \mathrm{l}$ & $2 \mathrm{U}$ \\
$\mathrm{H}_{2} \mathrm{O}$ & $17.5 \mu \mathrm{l}$ & - \\
\hline
\end{tabular}

CRITICAL STEP Include donor plasmid DNA in a separate reaction as a positive control for the PCR. 
52 Run the PCR reaction using the following conditions:

\begin{tabular}{l|c|c|c|c} 
Cycle number & Denature & Anneal & Extend & Hold \\
\hline 1 & $94^{\circ} \mathrm{C}, 5 \mathrm{~min}$ & & & \\
$2-31$ & $94^{\circ} \mathrm{C}, 1 \mathrm{~min}$ & $55^{\circ} \mathrm{C}, 30 \mathrm{~s}$ & $72^{\circ} \mathrm{C}, 30 \mathrm{~s}$ & \\
32 & & & $72^{\circ} \mathrm{C}, 7 \mathrm{~min}$ & \\
33 & & & & $4{ }^{\circ} \mathrm{C}$
\end{tabular}

53 Run a $5 \mu$ l aliquot of the PCR product on a $1 \%$ (wt/vol) agarose gel. A PCR product of $201 \mathrm{bp}$ in length indicates the presence of genomically integrated SB transposons. An example result of genotyping F1 rabbit offspring is shown in Fig. 5A.

\section{? TROUBLESHOOTING}

\section{Identification of individual transgene integrations by ligation-mediated PCR (LMPCR)}

1-2 weeks

54 Digest $1 \mu \mathrm{g}$ genomic DNA of F0 animals with Bfal, and in a separate reaction $1 \mu \mathrm{g}$ with Dpnll (Fig. 5B), in $50 \mu$ l final volumes. Include a negative control sample (genomic DNA isolated from a non-transgenic animal) as well. Follow the instructions of the enzyme supplier. To reach complete digestion, incubate the reaction for 3 hours at $37^{\circ} \mathrm{C}$.

CRITICAL STEP Always use high quality genomic DNA as template for PCR. Good quality genomic DNA runs on an agarose gel as a dominant, high molecular weight band (Fig. 5C).

55 Add $50 \mu \mathrm{l}$ phenol/chloroform/isoamyl alcohol to each tube. ! Caution This is a hazardous chemical. Avoid contact with skin, eyes and airways.

56 Vortex for $10 \mathrm{~s}$ and leave on the bench for 2 min. Repeat this step 3 times.

57 Centrifuge the samples at $12000 \times g$ for $5 \mathrm{~min}$ at room temperature.

58 Transfer the top layer $(-50 \mu \mathrm{l})$ to a new $1.5-\mathrm{ml}$ tube, add $5 \mu \mathrm{l}(1 / 10$ volume $)$ of sodium acetate and $125 \mu$ l (2.5 volumes) of ethanol, shake well and let the digested DNA precipitate for 30 min at $-20^{\circ} \mathrm{C}$. 
59 Spin down at $12000 \times g$ for $15 \mathrm{~min}$ at $4{ }^{\circ} \mathrm{C}$, and discard the supernatant.

CRITICAL STEP The pellet is barely visible. To avoid loss of DNA, remove the liquid using a $200 \mu \mathrm{l}$ pipette tip by touching only the wall of the tube that faced the inner side of the rotor.

61 Wash the pellet in cold $70 \%$ (vol/vol) ethanol. Keep the ethanol on the pellet for $10 \mathrm{~min}$.

61 Spin down at $12000 \times g$ for $15 \min$ at $4{ }^{\circ} \mathrm{C}$, and discard the supernatant.

CRITICAL STEP The pellet is barely visible. To avoid loss of DNA, remove the liquid using a $200 \mu$ I pipette tip by touching only the wall of the tube that faced the inner side of the rotor.

62 Air-dry the pellet for 5-10 min, and resuspend it in $20 \mu$ sterile Milli-Q water.

63 Measure the concentration of the digested DNA using a NanoDrop ${ }^{\circledR}$ spectrophotometer. The typical yield is between $30-50 \mathrm{ng} / \mu \mathrm{l}$.

64 To check digestion run 200 ng of each sample on a $1 \%(w t / v o l)$ agarose gel. The digested DNA should run as a smear centered between 0.5-1 kb in size (Fig. 5D).

Pause Point The digested genomic DNA samples can be stored at $20^{\circ} \mathrm{C}$ for up to 1 year.

65 Prepare the double-stranded linkers by mixing the Linker(+) oligo with the Linker(-)Bfal or with the Linker(-)Dpnll oligo (Table 1) in separate tubes at a final concentration of $10 \mathrm{pmol} / \mu \mathrm{l}$ of each oligo in $100 \mu \mathrm{l} \mathrm{TE} \mathrm{buffer} \mathrm{containing} 50 \mathrm{mM} \mathrm{NaCl}$.

66 Place the tubes containing the oligonucleotide solutions into a boiling water bath for 2 min, switch off the heating, and leave the tubes in the bath overnight to allow a slow cool down and hybridization of the two single-stranded oligonucleotides to form the double-stranded linker.

Pause Point The annealed double-stranded oligonucleotides can be stored at $-20^{\circ} \mathrm{C}$ for up to 1 year.

67 Ligate the Bfal linkers and the Dpnll linkers to the corresponding Bfal- and Dpnll-digested genomic DNA samples, respectively (Fig. 5B). Set up the ligation reaction containing the components below, and incubate overnight at $16^{\circ} \mathrm{C}$.

\begin{tabular}{|c|c|c|}
\hline Component & Amount per reaction & Final \\
\hline Ligase buffer (10x) & $5 \mu \mathrm{l}$ & $1 \mathrm{x}$ \\
\hline Bfal- or Dpnll-digested genomic DNA & $\mathrm{X} \mu \mathrm{l}$ & $150 \mathrm{ng}$ \\
\hline Annealed Bfal or Dpnll linker $(10 \mathrm{pmol} / \mu \mathrm{l})$ & $2 \mu \mathrm{l}$ & $20 \mathrm{pmol}$ \\
\hline T4 DNA Ligase & $3 \mu \mathrm{l}$ & $18 \cup$ \\
\hline $\mathrm{H}_{2} \mathrm{O}$ & $\mathrm{X \mu l}$ & to final volume of $50 \mu \mathrm{l}$ \\
\hline
\end{tabular}


68 Set up the $1^{\text {st }} \mathrm{PCR}$ in a $50 \mu$ reaction volume containing the components below:

\begin{tabular}{lll}
\hline Component & Amount per reaction & Final \\
\hline PCR buffer $(10 \mathrm{x})$ & $5 \mu \mathrm{l}$ & $1 \mathrm{x}$ \\
$\mathrm{MgCl}_{2}(25 \mathrm{mM})$ & $3 \mu \mathrm{l}$ & $1.5 \mathrm{mM}$ \\
$\mathrm{dNTP}(10 \mathrm{mM})$ & $1 \mu \mathrm{l}$ & $0.2 \mathrm{mM}$ \\
Linker Primer $(10 \mathrm{pmol} / \mu \mathrm{l})($ Table 1$)$ & $1 \mu \mathrm{l}$ & $10 \mathrm{pmol}$ \\
Tbal rev3s primer $(10 \mathrm{pmol} / \mu \mathrm{l})($ Table 1$)$ & $1 \mu \mathrm{l}$ & $10 \mathrm{pmol}$ \\
Ligated DNA (Step 67) & $2 \mu \mathrm{l}$ & - \\
Taq DNA polymerase & $0.5 \mu \mathrm{l}$ & $2.5 \mathrm{U}$ \\
$\mathrm{H}_{2} \mathrm{O}$ & $36.5 \mu \mathrm{l}$ & - \\
\hline
\end{tabular}

69 Run the $1^{\text {st }}$ PCR reaction using the following conditions:

\begin{tabular}{l|l|l|l|l} 
Cycle number & Denature & \multicolumn{1}{|c|}{ Anneal } & Extend & Hold \\
\hline 1 & $96{ }^{\circ} \mathrm{C}, 2 \mathrm{~min}$ & & & \\
$2-11$ & $92^{\circ} \mathrm{C}, 40 \mathrm{~s}$ & $60^{\circ} \mathrm{C}-1^{\circ} \mathrm{C} /$ cycle, $40 \mathrm{~s}$ & $72^{\circ} \mathrm{C}, 2 \mathrm{~min}$ & \\
$12-36$ & $92^{\circ} \mathrm{C}, 40 \mathrm{~s}$ & $50^{\circ} \mathrm{C}, 40 \mathrm{~s}$ & $72^{\circ} \mathrm{C}, 1 \mathrm{~min}$ & \\
37 & & & $72{ }^{\circ} \mathrm{C}, 10 \mathrm{~min}$ & \\
38 & & & & $4{ }^{\circ} \mathrm{C}$
\end{tabular}

70 Set up the $2^{\text {nd }} \mathrm{PCR}$ in a $50 \mu \mathrm{l}$ reaction volume containing the components below:

\begin{tabular}{lll}
\hline Component & Amount per reaction & Final \\
\hline PCR buffer $(10 \mathrm{x})$ & $5 \mu \mathrm{l}$ & $1 \mathrm{x}$ \\
$\mathrm{MgCl}_{2}(25 \mathrm{mM})$ & $3 \mu \mathrm{l}$ & $1.5 \mathrm{mM}$ \\
dNTP $(10 \mathrm{mM})$ & $1 \mu \mathrm{l}$ & $0.2 \mathrm{mM}$ \\
Nested Primer $(10 \mathrm{pmol} / \mu \mathrm{l})($ Table 1$)$ & $1 \mu \mathrm{l}$ & $10 \mathrm{pmol}$ \\
Tbal $(10 \mathrm{pmol} / \mu \mathrm{l})($ Table 1$)$ & $1 \mu \mathrm{l}$ & $10 \mathrm{pmol}$ \\
100x diluted $1^{\text {st }}$ PCR sample & $1 \mu \mathrm{l}$ & - \\
Taq DNA polymerase & $0.5 \mu \mathrm{l}$ & $2.5 \mathrm{U}$ \\
$\mathrm{H}_{2} \mathrm{O}$ & $37.5 \mu \mathrm{l}$ & - \\
\hline
\end{tabular}

71 Run the $2^{\text {nd }}$ PCR reaction using the following conditions:

\begin{tabular}{l|l|l|c|c} 
Cycle number & Denature & Anneal & Extend & Hold \\
\hline 1 & $96^{\circ} \mathrm{C}, 2 \mathrm{~min}$ & & \\
$2-7$ & $92^{\circ} \mathrm{C}, 40 \mathrm{~s}$ & $66^{\circ} \mathrm{C}-1^{\circ} \mathrm{C} /$ cycle, $40 \mathrm{~s}$ & $72^{\circ} \mathrm{C}, 1 \mathrm{~min}$ & \\
$8-21$ & $92^{\circ} \mathrm{C}, 40 \mathrm{~s}$ & $59^{\circ} \mathrm{C}, 40 \mathrm{~s}$ & $72^{\circ} \mathrm{C}, 1 \mathrm{~min}$ & \\
22 & & & $72^{\circ} \mathrm{C}, 10 \mathrm{~min}$ & \\
23 & & & & \\
& & & &
\end{tabular}


72 Run a $10-\mu l$ aliquot of the PCR product on a $1 \%$ (wt/vol) agarose gel. An example result is shown in Fig. 5E. Each band represents a unique transposon (transgene) genomic integration.

73 If strong, distinct bands are visible, isolate them from the gel using the QIAquick Gel Extraction Kit according to the manufacturer's instructions, and sequence them. Multiple bands often represent multiple integrations, and lower intensity bands may represent mosaic integrations - all of which need to be isolated from the gel, subcloned and sequenced. One should be able to identify the TA target dinucleotides immediately flanking the ITR in the genomic sequence, the Bfal and/or Dpnll recognition sites and the linkers that had been ligated to the DNA ends. The PCR amplifications applied in parallel on the Bfal- and Dpnll-digested DNA methods help the user to recover all integrations.

74 Map the insertion sites by a BLAT or BLAST search of the DNA sequence directly flanking the transposon, at the UCSC Genome Bioinformatics website (http://genome.ucsc.edu/cgi$\underline{\text { bin/hgBlat) }}$ or at the NCBI website (http://blast.ncbi.nlm.nih.gov/Blast.cgi).

\section{Tracking individual transgene integration sites by locus-specific PCR $\square$ TIIMING 1 week}

75 Design PCR primers matching the integration loci mapped in the founder animals (Step 74). Avoid designing primers that would bind to repetitive elements and thus amplify non-specific PCR products. The BLAT search at the UCSC Genome Bioinformatics website directly provides a RepeatMasker annotation of the genomic loci where the SB transposons have integrated. When using BLAST at the NCBI website select "map viewer" for a given BLAST hit, then select "maps \& options" and choose "repeats" to see the RepeatMasker annotation. After the identification of genomic regions free of repetitive sequences in the neighborhood of the SB ITR, design at least one locus-specific primer with a $T_{m}$ between $55-60^{\circ} \mathrm{C}$ and a length between $20-25$ nt. Run a BLAT or BLAST search with the new primer sequences to make sure that they do not bind to other genomic locations. In addition, general rules for PCR primer design can be found for example at http://www.premierbiosoft.com/tech notes/PCR Primer Design.html. 
76 Perform the locus-specific PCR with the primer designed in Step 75 and primer Tbal (Table 1) to trace specific transgene integrations by the presence or absence of an amplified product. To maximize specificity of primer annealing to the genomic target, the use of touchdown PCR is recommended consisting of 5-10 touchdown cycles stepwise decreasing the annealing temperature by $1^{\circ} \mathrm{C}$ per cycle down to the final annealing temperature, at about $2{ }^{\circ} \mathrm{C}$ below the $T_{m}$ of the lower $T_{m}$ primer, followed 25 additional standard cycles. Supplementary Fig. 1 shows an example of locus-specific PCR test of a rat founder and its F1 descendants.

\section{[CE: Table 1 is in the bottom of the manuscript.]}

\section{? TROUBLESHOOTING}

Troubleshooting advice can be found in Table 2 .

\section{TIMING}

Steps 1-13, preparation of transposon (transgene) donor plasmid: 2-4 $\mathrm{h}$

Steps 14-23, preparation of the transposase mRNA: 10-14 $\mathrm{h}$

Steps 24-26, preparation of the microinjection mixture: $1 \mathrm{~h}$

Step 27, superovulation and insemination of zygote donors: 5 days

Steps 28-34, zygote collection: 1-2 h

Steps 35-41, microinjection of zygotes: 1-3 h

Steps 42-49, reimplantation of injected zygotes: $15-30 \mathrm{~min} /$ recipient

Steps 50-53, genotyping of transgenic animals - confirming transposon insertions by PCR: 2.5 hours Steps 54-74, identification of individual transgene integration events by LMPCR: 1-2 weeks Steps 75-76, tracking individual transgene integration sites by locus-specific PCR: 1 week 
Table 2| Troubleshooting table.

\begin{tabular}{|c|c|c|c|}
\hline Step & Problem & Possible reason & Possible solution \\
\hline Step 22 & $\begin{array}{l}\text { Smear is } \\
\text { detected in the } \\
\text { size range } \\
\text { lower than } 800 \\
\text { bp. } \\
\text { More than two } \\
\text { bands are } \\
\text { detected. }\end{array}$ & $\begin{array}{l}\text { Different length products of } \\
\text { the in vitro mRNA synthesis. } \\
\text { The mRNA runs aberrantly } \\
\text { due to the formations of } \\
\text { secondary structures }\end{array}$ & $\begin{array}{l}\text { Consult the troubleshooting instructions of the } \\
\text { mMessage mMachine } ® \text { T7 kit. }\end{array}$ \\
\hline Step 33 & $\begin{array}{l}\text { Number of } \\
\text { collected } \\
\text { embryos is less } \\
\text { than } 20 \text { per } \\
\text { donor doe }\end{array}$ & Suboptimal donor animals. & $\begin{array}{l}\text { Do not use overweight or over-aged donor } \\
\text { rabbits. } \\
\text { The reproductive performance of rabbits is } \\
\text { seasonal, so some periods of the year (middle of } \\
\text { summer) are suboptimal for superovulation. }\end{array}$ \\
\hline Step 34 & $\begin{array}{l}\text { Poor embryo } \\
\text { quality. }\end{array}$ & $\begin{array}{l}\text { Bad quality semen. } \\
\text { Artifical insemination was } \\
\text { ineffective. } \\
\text { Embryos were overheated or } \\
\text { overexposed to light. }\end{array}$ & $\begin{array}{l}\text { Check the quality of the semen (motility of the } \\
\text { fresh semen should be over } 70 \% \text { ). } \\
\text { Check the insemination catheter. Insemination is } \\
\text { successful only when the semen remains } \\
\text { completely inside the reproductive tract. } \\
\text { Be sure that culture medium droplets are always } \\
\text { covered by mineral oil. Do not expose the } \\
\text { zygotes to excessive light. }\end{array}$ \\
\hline Step 43 & $\begin{array}{l}\text { Decreased } \\
\text { viability of the } \\
\text { injected } \\
\text { embryos (as of } \\
\text { lysed cell after } \\
\text { microinjection } \\
\text { Fig 4G) }\end{array}$ & $\begin{array}{l}\text { Toxicity due to excess } \\
\text { amounts of DNA in the } \\
\text { microinjection mixture. } \\
\text { Suboptimal culture } \\
\text { conditions. }\end{array}$ & $\begin{array}{l}\text { Carefully washing the precipitated plasmid DNA } \\
\text { and mRNA with } 70 \% \text { ethanol (Steps } 9 \text { and 18) is } \\
\text { important for the removal of residual } \\
\text { phenol/chloroform. } \\
\text { DEPC is not tolerated by the ova. Consequently, } \\
\text { RNase-free solutions that come in contact with } \\
\text { the injected material should be purified by } \\
\text { filtration. } \\
\text { Adjust the concentration of your construct } \\
\text { exactly. } \\
\text { Check the quality of the culture medium (pH, test } \\
\text { FCS before use). } \\
\text { Check the } \mathrm{CO}_{2} \text { incubator. Rabbit zygotes prefer } 5 \\
\% \mathrm{CO}_{2}, 38.5^{\circ} \mathrm{C} \text {. } \\
\text { Try to avoid applying strong negative pressure } \\
\text { while holding the zygotes. Inject the pronucleus } \\
\text { carefully. }\end{array}$ \\
\hline Step 49 & $\begin{array}{l}\text { Pups are not } \\
\text { born. }\end{array}$ & $\begin{array}{l}\text { Suboptimal reimplantation } \\
\text { procedure. }\end{array}$ & $\begin{array}{l}\text { Swelling of the oviduct during embryo transfer } \\
\text { should be visible. } \\
\text { Be sure not to damage the oviduct with the }\end{array}$ \\
\hline
\end{tabular}




\begin{tabular}{|c|c|c|c|}
\hline & $\begin{array}{l}\text { Litter size too } \\
\text { small or too } \\
\text { large. }\end{array}$ & Suboptimal embryo transfer. & $\begin{array}{l}\text { transferring needle. } \\
\text { Cultivate the injected embryos for at least } 72 \\
\text { hours in parallel with the embryo transfer - most } \\
\text { of the embryos should reach the early blastocyst } \\
\text { stage. Use special cultivation mediat }{ }^{45} \text {. } \\
\text { Too small litter sizes might cause skeletal } \\
\text { abnormalities of the overfed newborns. Too large } \\
\text { litter sizes ( } \geq 10) \text { might result in suboptimal } \\
\text { weight gain of the pups. Therefore the } \\
\text { equalization of litter sizes, or cross-feeding the } \\
\text { newborns with any other lactating doe which is } \\
\text { approximately in the same period of lactation is } \\
\text { an option. Please note that the age of the cross- } \\
\text { fed pups should be synchronized with the original } \\
\text { litter. } \\
\text { For more detailed advice from transgenic } \\
\text { experts, subscribe to transgenic-list at } \\
\text { http://www.transtechsociety.org/transgeniclist.php }\end{array}$ \\
\hline Step 53 & $\begin{array}{l}\text { No or few } \\
\text { transgenic } \\
\text { newborns } \\
\text { delivered }\end{array}$ & $\begin{array}{l}\text { Integrity of transposase } \\
\text { mRNA compromised. } \\
\text { Larger transgenes may } \\
\text { cause a drop of transgenesis } \\
\text { rates. }\end{array}$ & $\begin{array}{l}\text { Always use RNase-free laboratory plastic and } \\
\text { glassware and wear gloves while handling } \\
\text { reagents and samples to prevent RNase } \\
\text { contamination. } \\
\text { Do not re-use the same aliquot of the injection } \\
\text { mixture after microinjection (Step 26) due to the } \\
\text { increased risk of RNase contamination. } \\
\text { Increasing the amount of transposon (transgene) } \\
\text { donor plasmid in the final injection mixture } \\
\text { (preferably not over } 2 \text { ng/ul; Step 26) may help to } \\
\text { increase the efficiency in case of larger } \\
\text { transgenes. }\end{array}$ \\
\hline & & $\begin{array}{l}\text { Apparent low transgenic } \\
\text { rates may be due to } \\
\text { transgene detection } \\
\text { problems, e. g., because the } \\
\text { genomic DNA template used } \\
\text { in the PCR tests is } \\
\text { dearaded. }\end{array}$ & Always use high-quality genomic DNA for PCR. \\
\hline
\end{tabular}

\section{ANTICIPATE RESULTS}

The pregnancy rate of foster mothers is between $40-60 \%$, the ratio of pups born compared to the number of transferred microinjected embryos is around $10 \%$. The efficiency of Sleeping Beauty transgenesis in rabbits (transgenic founders in relation to all animals born alive) should be $15 \%$ or 
higher. We found germline transmission from F0 to F1 to be $100 \%$ with transgene segregation close to Mendelian rates $(44 \%)^{30}$. Germline transmission from F1 to F2 corresponded to the Mendelian rates for all rabbit lines with single-copy integration, which were confirmed by LMPCR (Fig. 5E). Transgene silencing was not experienced through three generations.

\section{Acknowledgements}

Z.B. was supported by the Hungarian grant OTKA NK 104397 and NN 108921. Research of V.L. was supported by grant TA02010013 from Technological Agency of the Czech Republic (TACR) and grant LH12061 from the Ministry of Education, Youth and Sports of the Czech Republic. Financial support by grants of the Deutsche Forschungsgemeinschaft (IV 21/6-1) to Z.Iv., and from the Austrian Genome Research Programme GEN-AU II and III (Austromouse) to T.R. is gratefully acknowledged.

Competing financial interest statement: The authors declare that they have no competing financial interests.

Author contribution statement: Z.IZ., Z.IV., Z.B. and L.H. designed the research, O.I.H., L.H., L.M., T.Y.Y., S.B., V.Z., M.P. and T.R. performed the experiments, Z.IV., A.G. and Z.IZ. analysed the data and Z.IV., Z.B. and L.H. wrote the manuscript.

\section{REFERENCES}

1. Flisikowska, T. et al. Efficient immunoglobulin gene disruption and targeted replacement in rabbit using zinc finger nucleases. PLoS One 6, e21045 (2011).

2. Catunda Lemos, A.P. et al. Characterization of the rabbit neonatal Fc receptor (FcRn) and analyzing the immunophenotype of the transgenic rabbits that overexpresses FcRn. PLoS One 7, e28869 (2012).

3. LaFerla, F.M. \& Green, K.N. Animal models of Alzheimer disease. Cold Spring Harb Perspect Med 2(2012).

4. Watanabe, Y. Serial inbreeding of rabbits with hereditary hyperlipidemia (WHHL-rabbit). Atherosclerosis 36, 261-8 (1980).

5. Shiomi, M., Ito, T., Yamada, S., Kawashima, S. \& Fan, J. Correlation of vulnerable coronary plaques to sudden cardiac events. Lessons from a myocardial infarction-prone animal model (the WHHLMI rabbit). J Atheroscler Thromb 11, 184-9 (2004). 
6. Brunner, M. et al. Mechanisms of cardiac arrhythmias and sudden death in transgenic rabbits with long QT syndrome. J Clin Invest 118, 2246-59 (2008).

7. Chader, G.J. Animal models in research on retinal degenerations: past progress and future hope. Vision Res 42, 393-9 (2002).

8. Kondo, M. et al. Generation of a transgenic rabbit model of retinal degeneration. Invest Ophthalmol Vis Sci 50, 1371-7 (2009).

9. Morimoto, T. et al. Transcorneal electrical stimulation promotes survival of photoreceptors and improves retinal function in rhodopsin P347L transgenic rabbits. Invest Ophthalmol Vis Sci 53, 4254-61 (2012).

10. Hammer, R.E. et al. Production of transgenic rabbits, sheep and pigs by microinjection. Nature 315, 680-3 (1985).

11. Brem, G. et al. YAC transgenesis in farm animals: rescue of albinism in rabbits. Mol Reprod Dev 44, 56-62 (1996).

12. Lillico, S., Vasey, D., King, T. \& Whitelaw, B. Lentiviral transgenesis in livestock. Transgenic Res 20, 441-2 (2011).

13. Hiripi, L. et al. Transgenic rabbit production with simian immunodeficiency virus-derived lentiviral vector. Transgenic Res 19, 799-808 (2010).

14. Yang, F. et al. Rabbit somatic cell cloning: effects of donor cell type, histone acetylation status and chimeric embryo complementation. Reproduction 133, 219-30 (2007).

15. Zakhartchenko, V. et al. Cell-mediated transgenesis in rabbits: chimeric and nuclear transfer animals. Biol Reprod 84, 229-37 (2011).

16. Chesne, P. et al. Cloned rabbits produced by nuclear transfer from adult somatic cells. Nat Biotechnol 20, 366-9 (2002).

17. Meng, Q., Polgar, Z., Liu, J. \& Dinnyes, A. Live birth of somatic cell-cloned rabbits following trichostatin A treatment and cotransfer of parthenogenetic embryos. Cloning Stem Cells 11, 203-208 (2009).

18. Ivics, Z., Hackett, P.B., Plasterk, R.H. \& Izsvak, Z. Molecular reconstruction of Sleeping Beauty, a Tc1-like transposon from fish, and its transposition in human cells. Cell 91, 501-10 (1997).

19. Ivics, Z. et al. Transposon-mediated genome manipulation in vertebrates. Nat Methods 6, 41522 (2009).

20. Zayed, H., Izsvak, Z., Walisko, O. \& Ivics, Z. Development of hyperactive sleeping beauty transposon vectors by mutational analysis. Mol Ther 9, 292-304 (2004).

21. Rostovskaya, M. et al. Transposon-mediated BAC transgenesis in human ES cells. Nucleic Acids Res 40, e150 (2012).

22. Voigt, K. et al. Retargeting sleeping beauty transposon insertions by engineered zinc finger DNA-binding domains. Mol Ther 20, 1852-62 (2012).

23. Moldt, B. et al. Comparative genomic integration profiling of Sleeping Beauty transposons mobilized with high efficacy from integrase-defective lentiviral vectors in primary human cells. Mol Ther 19, 1499-510 (2011).

24. Grabundzija, I. et al. Comparative analysis of transposable element vector systems in human cells. Mol Ther 18, 1200-9 (2010).

25. Ammar, I. et al. Retargeting transposon insertions by the adeno-associated virus Rep protein. Nucleic Acids Res 40, 6693-712 (2012).

26. Ivics, Z. \& Izsvak, Z. The expanding universe of transposon technologies for gene and cell engineering. Mob DNA 1, 25 (2010).

27. Ammar, I., Izsvak, Z. \& Ivics, Z. The Sleeping Beauty transposon toolbox. Methods Mol Biol 859, 229-40 (2012). 
28. Kaufman, C.D., Izsvak, Z., Katzer, A. \& Ivics, Z. Frog Prince transposon-based RNAi vectors mediate efficient gene knockdown in human cells. J RNAi Gene Silencing 1, 97-104 (2005).

29. Mates, L. et al. Molecular evolution of a novel hyperactive Sleeping Beauty transposase enables robust stable gene transfer in vertebrates. Nat Genet 41, 753-61 (2009).

30. Katter, K. et al. Transposon-mediated transgenesis, transgenic rescue, and tissue-specific gene expression in rodents and rabbits. FASEB J 27, 930-41 (2013).

31. Ivics, Z. et al. Germline Transgenesis in Rodents by Pronuclear Microinjection of Sleeping Beauty Transposons. Nature Protocols in press (2014).

\section{[CE: refs 31 and 33 are associated protocols.]}

32. Garrels, W. et al. Germline transgenic pigs by Sleeping Beauty transposition in porcine zygotes and targeted integration in the pig genome. PLoS One 6, e23573 (2011).

33. Ivics, Z. et al. Germline Transgenesis in Pigs by Cytoplasmic Microinjection of Sleeping Beauty Transposons. Nature Protocols in press (2014).

34. Ellis, J. Silencing and variegation of gammaretrovirus and lentivirus vectors. Hum Gene Ther 16, 1241-6 (2005).

35. Jahner, D. et al. De novo methylation and expression of retroviral genomes during mouse embryogenesis. Nature 298, 623-8 (1982).

36. Wolf, D. \& Goff, S.P. Embryonic stem cells use ZFP809 to silence retroviral DNAs. Nature 458, 1201-4 (2009).

37. Park, F. Lentiviral vectors: are they the future of animal transgenesis? Physiol Genomics 31, 159-73 (2007).

38. Claeys Bouuaert, C., Lipkow, K., Andrews, S.S., Liu, D. \& Chalmers, R. The autoregulation of a eukaryotic DNA transposon. Elife 2, e00668 (2013).

39. Ro, H., Soun, K., Kim, E.J. \& Rhee, M. Novel vector systems optimized for injecting in vitrosynthesized mRNA into zebrafish embryos. Mol Cells 17, 373-6 (2004).

40. O'Malley, R.C., Alonso, J.M., Kim, C.J., Leisse, T.J. \& Ecker, J.R. An adapter ligationmediated PCR method for high-throughput mapping of T-DNA inserts in the Arabidopsis genome. Nat Protoc 2, 2910-7 (2007).

41. Ivics, Z., Izsvak, Z., Medrano, G., Chapman, K.M. \& Hamra, F.K. Sleeping Beauty transposon mutagenesis in rat spermatogonial stem cells. Nat Protoc 6, 1521-35 (2011).

42. Besenfelder, U. \& Brem, G. Laparoscopic embryo transfer in rabbits. J Reprod Fertil 99, 53-6 (1993).

43. Murakami, H. \& Imai, H. Successful implantation of in vitro cultured rabbit embryos after uterine transfer: a role for mucin. Mol Reprod Dev 43, 167-70 (1996).

44. Laird, P.W. et al. Simplified mammalian DNA isolation procedure. Nucleic Acids Res 19, 4293 (1991).

45. Mitalipov, S.M., White, K.L., Farrar, V.R., Morrey, J. \& Reed, W.A. Development of nuclear transfer and parthenogenetic rabbit embryos activated with inositol 1,4,5-trisphosphate. Biol Reprod 60, 821-7 (1999). 


\section{FIGURE LEGENDS}

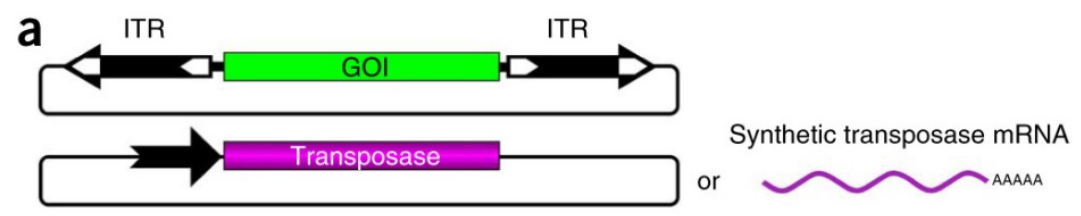

b

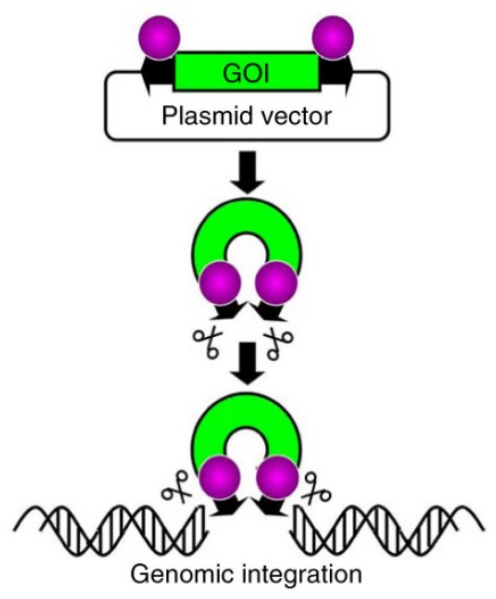

Figure 1. Application of Sleeping Beauty transposons for gene delivery. (A) A bi-component transposon system for delivering transgenes in plasmids. One component contains a gene of interest (GOI) cloned between the transposon inverted terminal repeats (ITR, black arrows) encoded by a plasmid. The other component is either a transposase expression plasmid, or synthetic mRNA encoding the transposase. (B) The transposon carrying a GOI is excised from the donor plasmid and is integrated at a chromosomal site by the transposase (purple spheres). 


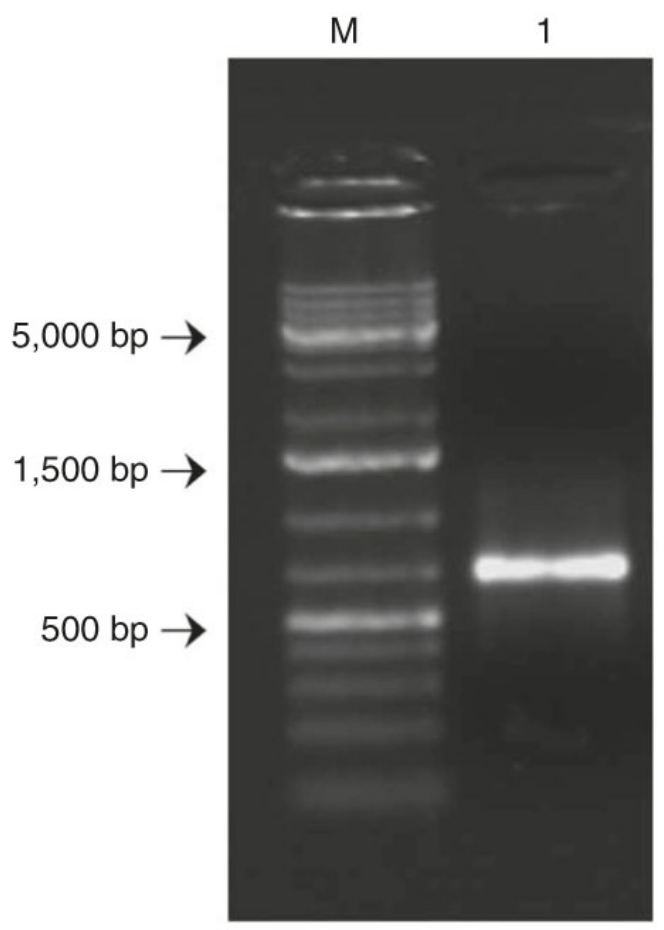

Figure 2. In vitro mRNA synthesis. mRNA quality can be determined by standard agarose electrophoresis and ethidium bromide staining. Samples run on $1 \%$ RNase-free non-denaturing agarose gel. Lanes: M, DNA size marker; $1,1 \mu \mathrm{l}$ in vitro synthesized SB100X mRNA. 
Donor females

Superovulation protocol option A

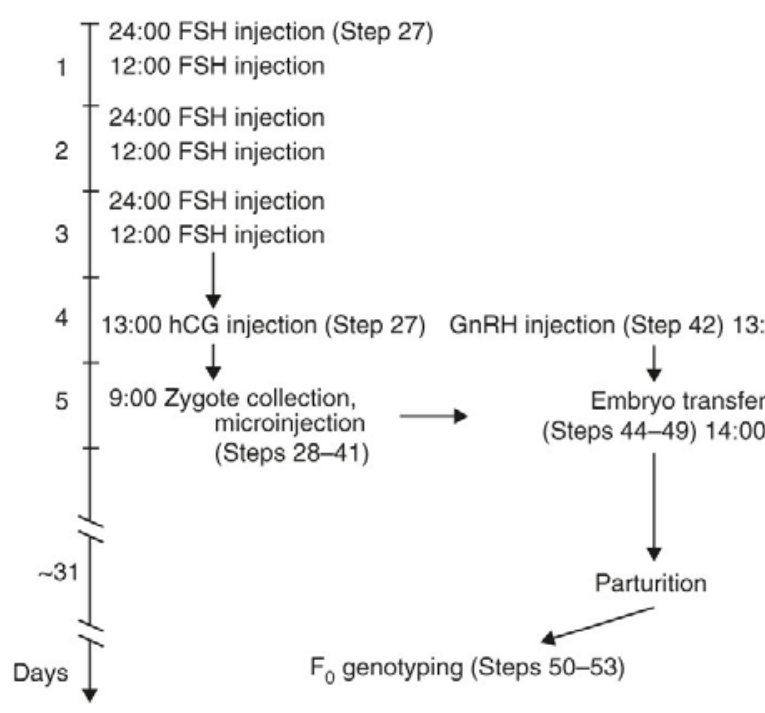

Recipient does

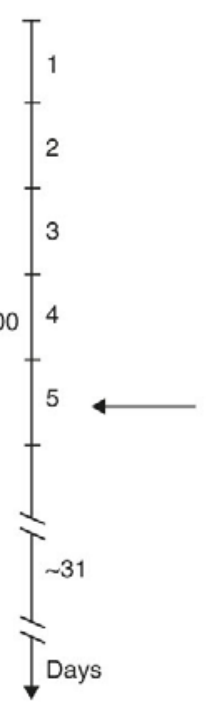

Donor females

Superovulation protocol option B

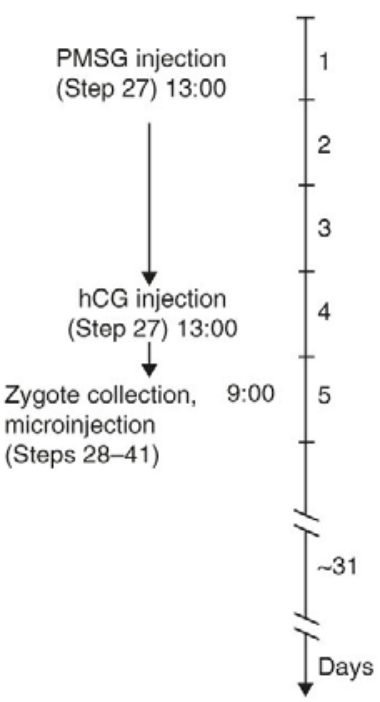

Figure 3. Timelines for rabbit manipulations. Timing (in days) of the important protocol steps for donor hormonal treatment (A) and (B), ending with parturition and genotyping of the F0-offspring. 

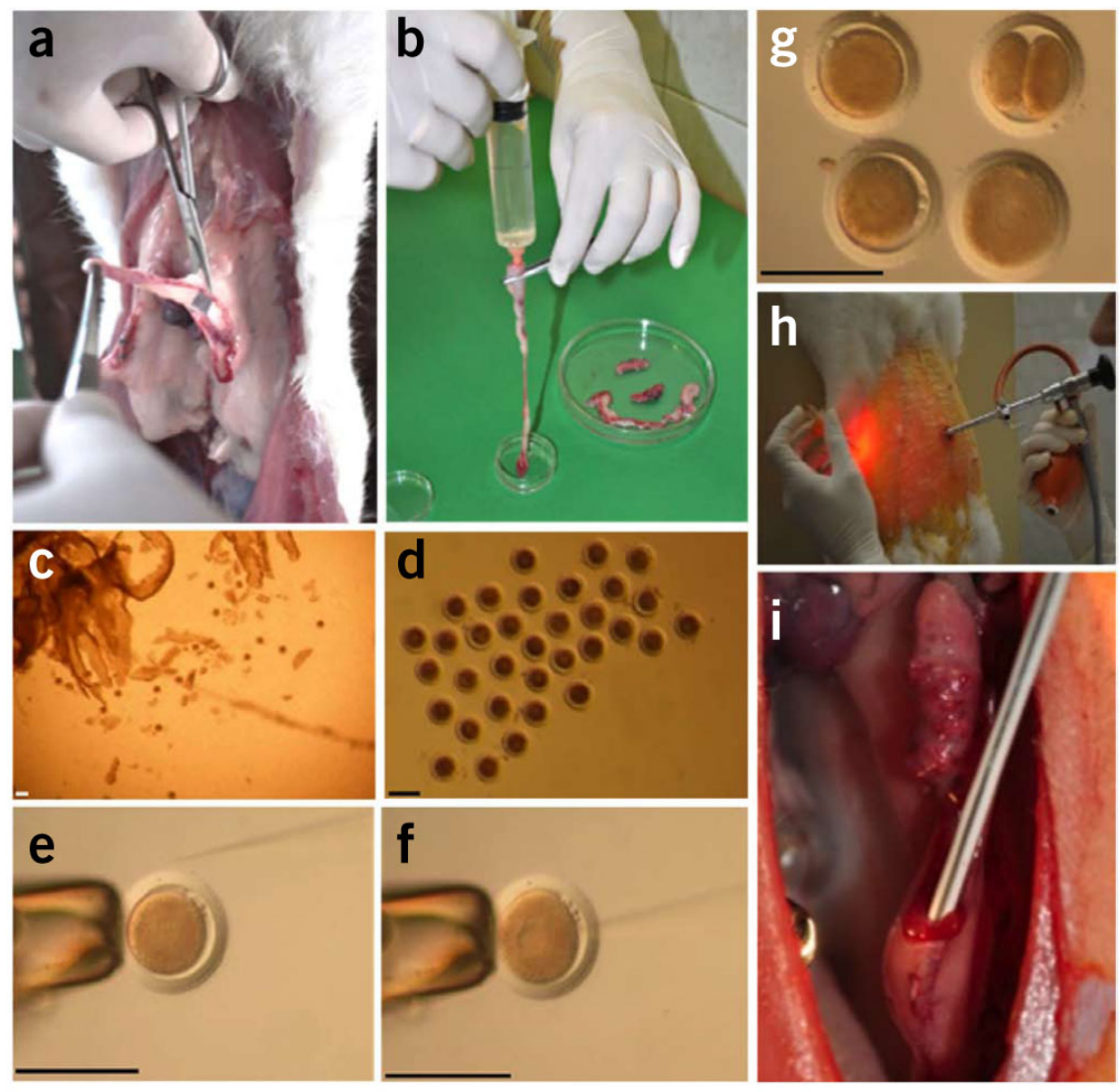

Figure 4. Overview of rabbit transgenesis. (A) Excision of reproductive organs from donors. (B) Embryo flushing. (C) and (D) Embryo collection in rabbits. Good quality embryos are free of cumulus cells and have two easily detectable pronuclei. (E) A rabbit zygote before microinjection. (F) Zygote with swelling pronucleus. (G) Different zygotes clockwise: zygote with reduced visibility of pronuclei, two-cell-stage embryo, lysed cell after microinjection, an ideal zygote for embryo transfer. (H) Positioning of the cannula and the obtulator with Hopkins telescope during endoscopic transfer. (I) Simulated embryo transfer. Note the quality of the ovary and the cannula in the oviduct. 


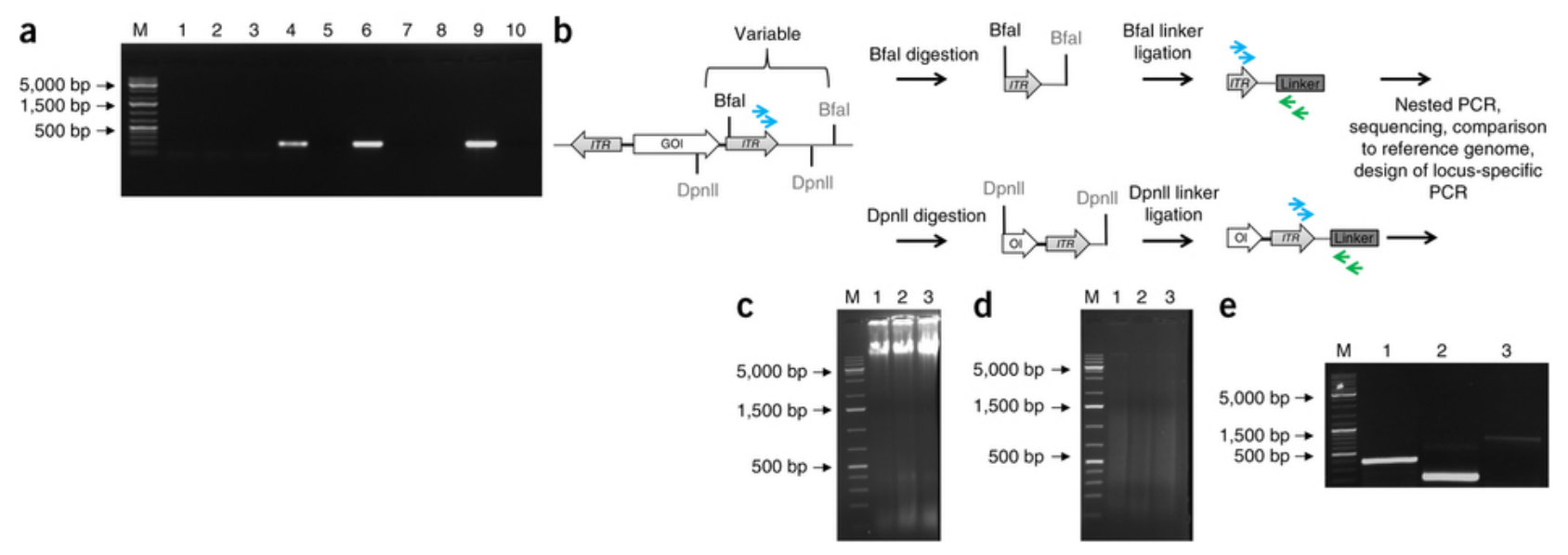

Figure 5. Identification of transgene integration by PCR. (A) Identification of integrated transposon sequences from rabbit genomic DNA samples by PCR with primers that amplify the left ITR of SB. (B) Outline of the LMPCR procedure. Digestion of genomic DNA with the frequently cutting restriction enzymes Bfal and Dpnll and ligation of linkers with a known sequence allows for specific LMPCR amplification of transposon/genomic DNA junctions using primers specific to the transposon ITR (blue arrows) and the linkers (green arrows). Linker-to-linker amplifications are blocked by the 3'-amino modifications of the Linker(-) oligo ${ }^{40}$ (Table 1). Amplification products are sequenced for comparison to the reference genome. GOI, gene of interest; ITR, inverted terminal repeat. (C) Agarose gel with $500 \mathrm{ng}$ genomic DNA samples prepared from rabbit founders. M, DNA size marker. (D) Agarose gel with $200 \mathrm{ng}$ Bfal-digested genomic DNA samples of rabbit founders. M, DNA size marker. (E) Agarose gel with LMPCR products. M, DNA size marker. 

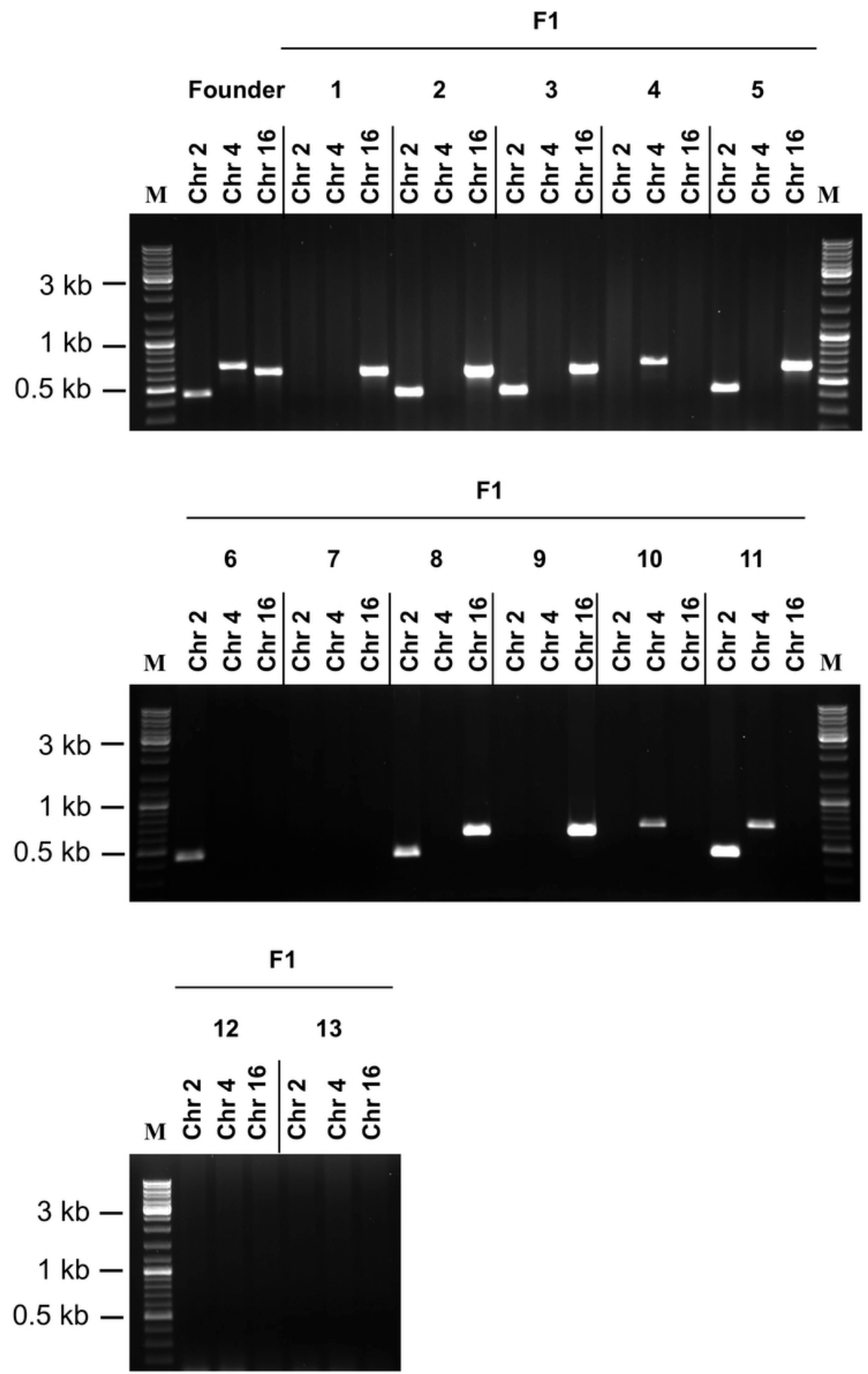

Supplementary Figure 1: Locus-specific PCR test of a rat founder and its F1 descendants. The founder of these $\mathrm{F}_{1}$ animals carried three SB integrations (in chr2, chr4 and chr16), which were transmitted to 13 descendants in different combinations. M, DNA size marker. 
Table 1. Primer sequences

\begin{tabular}{|c|c|c|}
\hline $\begin{array}{l}\text { Oligo } \\
\text { designation }\end{array}$ & Sequence & Description and use \\
\hline SB short & 5'-TACAGTTGAAGTCGGAAGTTTACATAC-3' & $\begin{array}{l}\text { Transposon-specific } \\
\text { primer used in PCR with } \\
\text { Tbal rev. Step } 51\end{array}$ \\
\hline Tbal rev & 5'-GAATTGTGATACAGTGAATTATAAGTG-3' & $\begin{array}{l}\text { Transposon-specific } \\
\text { primer used in PCR with } \\
\text { SB short. Step } 51\end{array}$ \\
\hline Linker(+) & $\begin{array}{l}\text { 5'-GTAATACGACTCACTATAGGGCTCCG } \\
\text { CTTAAGGGAC-3' }\end{array}$ & $\begin{array}{l}\text { Annealed either with } \\
\text { Linker(-) Bfal or Linker(-) } \\
\text { Dpnll to form double } \\
\text { stranded linker for LM- } \\
\text { PCR. Step } 65\end{array}$ \\
\hline Linker(-)Bfal & 5'-p-TAGTCCCTTAAGCGGAG-Amino-3' & $\begin{array}{l}\text { Annealed with Linker(+). } \\
\text { The 3' C } 7 \text { amino } \\
\text { modification prevents } \\
\text { polymerase extension. } \\
\text { Step } 65\end{array}$ \\
\hline Linker(-)DpnII & 5'-p-GATCGTCCCTTAAGCGGAG-Amino-3' & $\begin{array}{l}\text { Annealed with Linker(+). } \\
\text { The 3' C7 amino } \\
\text { modification prevents } \\
\text { polymerase extension. } \\
\text { Step } 65\end{array}$ \\
\hline Linker Primer & 5'-GTAATACGACTCACTATAGGGC-3' & $\begin{array}{l}\text { Linker-specific primer } \\
\text { used in the first round of } \\
\text { PCR with Tbal rev3s } \\
\text { (transposon specific). } \\
\text { Step 68 }\end{array}$ \\
\hline Tbal rev3s & 5'-CATGACATCATTTTCTGGAATT-3' & $\begin{array}{l}\text { Transposon-specific } \\
\text { primer used in the first } \\
\text { round of PCR with } \\
\text { Linker Primer (linker } \\
\text { specific). Step } 68\end{array}$ \\
\hline Nested Primer & 5'-AGGGCTCCGCTTAAGGGAC-3' & $\begin{array}{l}\text { Linker-specific primer } \\
\text { used in the second } \\
\text { round of PCR with Tbal } \\
\text { (transposon specific). } \\
\text { Step } 70\end{array}$ \\
\hline Tbal & 5'-CTTGTGTCATGCACAAAGTAGATGTCC-3' & $\begin{array}{l}\text { Transposon-specific } \\
\text { primer used in the } \\
\text { second round of PCR } \\
\text { with Nested Primer } \\
\text { (linker specific). Step } 70\end{array}$ \\
\hline
\end{tabular}

